\title{
PENERAPAN MODEL PEMBELAJARAN INKUIRI TERBIMBING UNTUK MENINGKATKAN KEMAMPUAN BERPIKIR KRITIS DAN SIKAP ILMIAH SISWA SMA
}

\author{
G.A.P.U.Parwati ${ }^{1}$, N.K.Rapi ${ }^{2}$, D.O.Rachmawati ${ }^{3}$ \\ $1,2,3$ Jurusan Fisika dan Pengajaran IPA, Universitas Pendidikan Ganesha, Singaraja \\ e-mail: putu.ulan.parwati@undiksha.ac.id, ketut.rapi@undiksha.ac.id, dewioktofa.r@undiksha.ac.id
}

\begin{abstract}
Abstrak
Penelitian ini dilatarbelakangi oleh adanya permasalahan rendahnya kemampuan berpikir kritis dan sikap ilmiah siswa dalam pelajaran fisika di kelas X IPA 2 SMA Negeri 1 Kuta. Alternatif solusi dari permasalahan tersebut adalah penerapan model pembelajaran inkuiri terbimbing. Penelitian ini bertujuan untuk meningkatkan kemampuan berpikir kritis, sikap ilmiah siswa, dan mendeskripsikan tanggapan siswa terhadap penerapan model pembelajaran inkuiri terbimbing dalam pelajaran fisika. Jenis penelitian ini adalah penelitian tindakan kelas (PTK). Subjek penelitian ini adalah siswa kelas $X$ IPA 2 pada semester genap tahun pelajaran 2019/2020 sebanyak 35 orang siswa yang terdiri dari 17 orang siswa laki-laki dan 18 orang siswa perempuan. Penelitian ini terdiri dari 2 siklus. Data kemampuan berpikir kritis siswa diperoleh dari tes kemampuan berpikir kritis. Data sikap ilmiah siswa dan data tanggapan siswa terhadap model pembelajaran inkuiri terbimbing diperoleh melalui angket. Data yang diperoleh dianalisis secara deskriptif kuantitatif. Hasil penelitian ini menunjukkan bahwa: (1) kemampuan berpikir kritis siswa siklus I berada pada kategori baik ( $\bar{X}=76,37, S D=7,76)$ dengan KK $91,43 \%$ dan siklus II berada pada kategori sangat baik ( $\bar{X}=89,58, S D=6,60)$ dengan KK $100 \%$, (2) sikap ilmiah siswa siklus I berada pada kategori tinggi ( $\bar{X}=110,60, S D=7,39)$ dan siklus II juga berada pada kategori tinggi ( $\bar{X}=118,83, S D=7,35$ ), (3) tanggapan siswa terhadap penerapan model pembelajaran inkuiri terbimbing berada pada kategori positif ( $\bar{X}=114,11, S D=6,55$ ). Simpulan hasil penelitian ini adalah penerapan model pembelajaran inkuiri terbimbing meningkatkan kemampuan berpikir kritis dan sikap ilmiah siswa dalam pelajaran fisika dan siswa menunjukkan tanggapan positif terhadap penerapan model pembelajaran inkuiri terbimbing.
\end{abstract}

Kata-kata kunci: model pembelajaran inkuiri terbimbing, kemampuan berpikir kritis, sikap ilmiah.

\begin{abstract}
This research was motivated by the problem of the low of students' critical thinking ability and scientific attitudes in physics lesson in class XIPA 2 of SMA Negeri 1 Kuta. An alternative solution to the problem is the implementation of guided inquiry learning models. This study aimed at improving the students' critical thinking ability and scientific attitudes, and describing the students' responses to the implementation of guided inquiry learning models in physics lesson. The type of this research was classroom action research (CAR). The subjects of this study were 35 students of class X IPA 2 in the even semester of 2019/2020 which consisted of 17 male students and 18 female students. This research consisted of 2 cycles. The data of students' critical thinking ability were obtained by the tests of critical thinking ability, while the data of students' scientific attitudes and data of students' responses toward the guided inquiry learning model were obtained through a questionnaire. The data were analyzed quantitatively. The results of this study indicate that: (1) the students' critical thinking ability in the first cycle is in the good category ( $\bar{X}=76,37, S D=7,76)$ with $K K 91,43 \%$ and in the second cycle is in the very good category ( $\bar{X}=89,58, S D=6,60)$ with $K K 100 \%$, (2) the students' scientific attitude in the first cycle is in the high category $(\bar{X}=110,60, S D=7,39)$ and in the second cycle was also in the high category ( $\bar{X}=76,37, S D=7,35)$, (3) Students' responses toward the implementation of guided inquiry learning models were in positive category $(\bar{X}=114,11, S D=6,55)$. The conclusions of the results of this study are that the implementation of guided inquiry learning models increase the students' critical thinking ability and scientific attitudes in physics lesson and the students show positive responses toward the implementation of guided inquiry learning models.
\end{abstract}

Keywords: guided inquiry learning model, critical thinking ability, scientific attitude.

\section{PENDAHULUAN}


Era revolusi industri 4.0 ditandai dengan teknologi digital yang berkembang pesat. Hal ini merupakan tantangan bagi pembelajaran pada abad ke-21 agar setiap individu untuk memiliki keterampilan berpikir dan penguasaan teknologi yang siap berkompetisi dan memenangkan persaingan yang semakin ketat dengan negara lain. Salah satu keterampilan yang harus dimiliki adalah learning and innovation skills 4C yang terdiri dari empat aspek, yaitu kemampuan berpikir kritis (critical thinking), kemampuan berkomuniskasi (communication), bekerja sama dan kolaborasi (collaboration), dan kreativitas (creativity). Sumber daya manusia yang berkualitas dengan keterampilan berpikir dan penguasaan teknologi dapat ditingkatkan salah satunya melalui pendidikan.

Pendidikan yang mampu mempersiapkan siswa untuk mampu menghadapi kemajuan teknologi adalah pendidikan dengan pembelajaran yang berpusat pada siswa. Pembelajaran berpusat pada siswa bertujuan untuk membangun struktur kognitifnya melalui data, teori, atau fakta yang diamati oleh siswa terutama pada pembelajaran sains seperti pembelajaran fisika. Salah satu tujuan mata pelajaran fisika di SMA/MA diantaranya: (1) sebagai sarana memupuk sikap ilmiah siswa; (2) menghargai kerja individu dan kelompok; dan (3) mengembangkan kemampuan bernalar dalam analisis induktif dan deduktif dengan konsep dan prinsip fisika (Permendikbud No. 59, 2014). Berdasarkan tujuan mata pelajaran fisika tersebut maka dalam proses penyelenggaraannya harus menjadi sarana untuk melatih siswa memiliki kemampuan berpikir kritis dan mempunyai sikap ilmiah tinggi. Seranica, Purwoko, dan Hakim (2018) menyatakan bahwa salah satu pemikiran tingkat tinggi yang harus dimiliki siswa adalah proses berpikir kritis karena melalui pemikiran kritis dapat melatih siswa untuk menganalisis masalah dan menyelesaikan masalah di bidang sains. Selain berpikir kritis, sikap ilmiah termasuk ke dalam karakter pendidikan yang harus dimiliki oleh siswa, dan implementasi pembelajaran diharapkan mampu melatih sikap ilmiah siswa. Sikap ilmiah menggambarkan keterbukaan pikiran, rasa ingin tahu, dan pendekatan optimis terhadap kegagalan sebagai nilai-nilai pelatihan ilmiah (Wildan, Hakim, Siahaan, \& Anwar, 2019).

Salah satu cara yang telah dilakukan oleh pemerintah Indonesia untuk meningkatkan dan mengembangkan kemampuan berpikir kritis dan sikap ilmiah siswa, yaitu dengan memperbaiki kualitas mutu pendidikan di Indonesia dengan menerapkan Kurikulum 2013 revisi 2016. Kurikulum 2013 menerapkan pendekatan saintifik (scientific approach) dalam proses belajar mengajar. Pendekatan saintifik adalah pendekatan yang akan membentuk individu untuk memiliki sikap kritis dan berkarakter (Nurdin et al. 2018). Melalui penerapan Kurikulum 2013 dengan menggunakan pendekatan saintifik pada pembelajaran fisika diharapkan dapat mengembangkan dan meningkatkan kemampuan berpikir kritis dan sikap ilmiah siswa.

Namun, pada kenyataannya masih terdapat siswa yang mempunyai kemampuan berpikir kritis dan sikap ilmiah yang rendah. Hal ini juga diungkapkan dalam penelitian Nisa, Koestiari, Habibbulloh, dan Jatmiko (2017) yang mengungkapkan bahwa keterampilan berpikir kritis fisika pada topik Hukum Hooke masih relatif rendah. Laila dan Lufri (2019) menyatakan bahwa, implementasi tujuan dan fungsi pendidikan belum sepenuhnya terlaksanya di lapangan yang disebabkan karena menurunya sikap dan karakter bangsa, serta berdasarkan pengamatan diperoleh bahwa proses pembelajaran masih menyoroti aspek kognitif tanpa melihat bagaimana perubahan sikap siswa.

Berdasakan observasi awal dalam pembelajaran fisika di kelas X IPA 2 SMA Negeri 1 Kuta Tahun Pelajaran 2019/2020 diperoleh beberapa temuan, yaitu (1) partisipasi siswa dalam memberikan argumen masih rendah, (2) pada tahap mendeduksi suatu peristiwa atau fenomena siswa masih kesulitan dalam menginterpretasi terhadap peristiwa yang dipaparkan, (3) untuk tahap induksi siswa banyak yang kurang mampu dalam menganalisis data, sehingga sulit untuk menarik kesimpulan, (4) untuk tahap evaluasi siswa cukup mampu dalam melakukan evaluasi berdasarkan fakta dan teori, dan (5) siswa belum mampu untuk memberikan solusi dari permasalahan, sehingga siswa kurang mampu dalam memutuskan dan melaksanakan alternatif solusi berdasarkan teori yang diperoleh dari permasalahan yang ada.

Selain itu, hasil observasi awal dan wawancara di sekolah mengenai sikap ilmiah, yaitu: (1) rasa ingin tahu siswa rendah dilihat dari sedikit siswa yang mengajukan pertanyaan 
saat pembelajaran di kelas, (2) siswa masih mengerjakan soal-soal latihan dari buku pegangan siswa yang dikerjakan secara individu, sehingga siswa belum menunjukkan sikap fleksibilitas dalam cara berpikir seperti menghargai pendapat teman dan mengubah pandangan semula ketika bertentangan dengan data atau fakta-fakta yang diperoleh berdasarkan hasil praktikum, (3) pembelajaran masih menggunakan metode ceramah menyebabkan siswa kurang respek terhadap fakta, dan (4) siswa belum menunjukkan sikap peka terhadap lingkungan dilihat dari masih terdapat siswa yang tidak menjaga kebersihan kelasnya. Permasalahan ini didukung oleh hasil ulangan harian fisika siswa kelas X IPA 2 SMA Negeri 1 Kuta semester ganjil Tahun Pelajaran 2019/2020 yang diperoleh pada observasi awal terungkap nilai rata-rata siswa yang dapat dilihat pada Tabel 1.

Tabel 1. Data Hasil Ulangan Harian Siswa Kelas X IPA 2 SMA Negeri 1 Kuta

\begin{tabular}{ccccccc}
\hline Kelas & $\begin{array}{c}\text { Jumlah } \\
\text { Peserta }\end{array}$ & $\begin{array}{c}\text { Jumlah } \\
\text { Tuntas }\end{array}$ & $\begin{array}{c}\text { Nilai } \\
\text { Rata-rata }\end{array}$ & KK & $\begin{array}{c}\text { Nilai } \\
\text { Tertinggi }\end{array}$ & $\begin{array}{c}\text { Nilai } \\
\text { Terendah }\end{array}$ \\
\hline X IPA 1 & 35 & 15 & 67,00 & $42,85 \%$ & 90 & 40 \\
X IPA 2 & 35 & 7 & 55,71 & $20,00 \%$ & 85 & 20 \\
X IPA 3 & 36 & 11 & 61,38 & $30,56 \%$ & 95 & 35 \\
X IPA 4 & 36 & 14 & 65,27 & $38,89 \%$ & 95 & 30 \\
X IPA 5 & 36 & 10 & 62,08 & $27,78 \%$ & 90 & 40 \\
X IPA 6 & 36 & 9 & 66,53 & $25,00 \%$ & 80 & 60 \\
X IPA 7 & 31 & 12 & 67,74 & $38,71 \%$ & 90 & 50 \\
X IPA 8 & 36 & 10 & 64,30 & $27,78 \%$ & 75 & 55 \\
X IPA 9 & 33 & 8 & 63,18 & $24,24 \%$ & 80 & 50 \\
\hline
\end{tabular}

(Sumber: Arsip SMA Negeri 1 Kuta)

Kriteria Ketuntasan Maksimum (KKM) siswa yang diberlakukan pada pelajaran fisika kelas X IPA adalah 70. Jumlah siswa kelas X IPA 2 yang memenuhi KKM adalah 7 orang dari total 35 orang siswa. Tampak bahwa nilai kelas X IPA 2 secara klasikal lebih rendah dari pada delapan kelas yang lainnya. Hal ini merupakan permasalahan yang harus diatasi.

Indikasi permasalahan yang terjadi di kelas X IPA 2 SMA Negeri 1 Kuta tentu terjadi karena suatu penyebab. Berdasarkan hasil wawancara dan observasi ditemukan beberapa temuan, yaitu (1) pembelajaran yang dilakukan oleh guru masih konvensional, sehingga proses pembelajaran cenderung berpusat pada guru (teacher center learning), (2) tidak pernah dilakukan praktikum ataupun demonstrasi alat, (3) siswa tidak tertarik terhadap pembelajaran fisika karena dianggap sulit, siswa menganggap pelajaran fisika sebagai pelajaran menghapal rumus-rumus dan materi, dan (4) kurangnya interaksi siswa.

Kesenjangan yang terjadi disebabkan karena penerapan pembelajaran yang berpusat pada guru dan tidak pernah diadakan demonstrasi alat atau praktikum selama pembelajaran. Laila dan Lufri (2019) mengemukakan bahwa rendahnya sikap ilmiah siswa disebabkan karena model pembelajaran yang digunakan oleh guru masih konvensional. Hajrin, Sadia, dan Gunadi (2019) menyatakan bahwa penyebab rendahnya keterampilan berpikir kritis siswa dikarenakan model pembelajaran yang digunakan guru kurang bervariasi.

Solusi yang dapat diterapkan untuk mengatasi permasalahan di kelas X IPA 2 SMA Negeri 1 Kuta adalah dengan penerapan model pembelajaran inkuiri terbimbing. Model pembelajaran ini yang dalam kegiatan pembelajaran melibatkan kemampuan siswa dalam menyelidiki sesuatu melalui kegiatan percobaan sehingga siswa dapat menemukan sendiri pengetahuannya. Selain itu, model pembelajaran ini menekankan proses menemukan sehingga dapat mendorong keaktifan siswa dalam belajar serta menumbuhkan kemampuan berpikir kritis siswa dan sikap ilmiah siswa. Model pembelajaran inkuiri terbimbing sesuai dengan teori konstruktivistik di mana siswa harus aktif membangun pengetahuannya sendiri bukan menerima informasi yang diberikan oleh pendidik.

Berdasarkan penelitian yang telah dilakukan oleh Cahyani dan Azizah (2019) menemukan bahwa model pembelajaran inkuiri terbimbing dapat meningkatkan keterampilan berpikir kritis. Senada dengan penelitian tersebut, Senada dengan penelitian tersebut, Siburian, Corebima, Ibrohim, dan Saptasari (2019) mengemukakan bahwa terdapat 
hubungan yang signifikan antara keterampilan berpikir kritis dan keterampilan berpikir kreatif terhadap hasil belajar kognitif dengan penerapan strategi inkuiri. Selain itu, penelitian Fadilah, Purwanto, dan Risdianto (2018) menemukan bahwa model pembelajaran inkuiri terbimbing dapat meningkatkan sikap ilmiah siswa. Fauzia, Badaruddin, dan Supriatna (2019) menemukan bahwa model pembelajaran inkuiri terbimbing dapat melatih siswa berpikir kritis dan sikap ilmiah agar dapat mengembangkan kemampuan memecahkan masalah.

Berdasarkan penelitian-penelitian tersebut menunjukkan bahwa penerapan model pembelajaran inkuiri terbimbing dapat meningkatkan kemampuan berpikir kritis dan sikap ilmiah siswa dalam pembelajaran fisika. Oleh karena itu peneliti melakukan penelitian dengan judul "Penerapan Model Pembelajaran Inkuiri Terbimbing untuk Meningkatkan Kemampuan Berpikir Kritis dan Sikap IImiah Siswa dalam Pelajaran Fisika Kelas X IPA 2 SMA Negeri 1 Kuta".

Fisher (2009) menyatakan bahwa berpikir kritis adalah aktivitas yang terampil dan aktif terhadap observasi, komunikasi, informasi, dan argumentasi. Ennis (dalam Costa, 1991) memaparkan enam dimensi kemampuan berpikir kritis, yaitu: (1) merumuskan masalah, (2) memberikan argumen, (3) melakukan deduksi, (4) melakukan induksi, (5) melakukan evaluasi, dan (6) memutuskan dan melaksanakan.

Harlen dan Qualter (2004) menyatakan bahwa sikap merupakan kesediaan untuk bertindak dengan cara tertentu dalam keadaan tertentu. Harlen (2000) mengelompokkan sikap ilmiah menjadi lima dimensi, yaitu sikap ingin tahu, sikap respek terhadap data atau fakta, sikap fleksibilitas dalam cara berpikir, sikap berpikir kritis, dan sikap peka terhadap lingkungan.

Model pembelajaran inkuiri merupakan pembelajaran yang memberikan penekanan pada pengembangan intelektual peserta didik melalui kegiatan-kegiatan penemuan (Sadia, 2014). Terdapat enam langkah pembelajaran inkuiri, yaitu: (1) merumuskan masalah, (2) mengajukan hipotesis, (3) merancang dan melakukan eksperimen, (4) mengumpulkan dan mengolah data, (5) interpretasi hasil analisis data dan pembahasan, dan (6) menarik kesimpulan.

Tujuan penelitian ini, yaitu: (1) meningkatkan kemampuan berpikir kritis siswa kelas $X$ IPA 2 SMA Negeri 1 Kuta melalui penerapan model pembelajaran inkuiri terbimbing, (2) meningkatkan sikap ilmiah siswa kelas X IPA 2 SMA Negeri 1 Kuta melalui penerapan model pembelajaran inkuiri terbimbing, dan (3) mendeskripsikan tanggapan siswa kelas X IPA 2 SMA Negeri 1 Kuta terhadap penerapan model pembelajaran inkuiri terbimbing.

\section{METODE}

Penelitian ini merupakan penelitian tindakan kelas (PTK) atau classroom action research berupa penerapan model pembelajaran inkuiri terbimbing dalam pelajaran fisika yang dilaksanakan di SMA Negeri Subjek dalam penelitian ini adalah seluruh siswa kelas $X$ IPA 2 SMA Negeri 1 Kuta semester genap Tahun Pelajaran 2019/2020, dengan rincian 35 orang siswa, terdiri dari 17 orang siswa laki-laki dan 18 orang siswa perempuan. Objek penelitian ini adalah model pembelajaran inkuiri terbimbing, kemampuan berpikir kritis, sikap ilmiah, dan tanggapan siswa terhadap penerapan model pembelajaran inkuiri terbimbing. Penelitian tindakan kelas ini dilaksanakan dalam dua siklus, yaitu siklus I dan siklus II. Masing-masing siklus terdiri dari empat tahapan, yaitu perencanaan (planning), pelaksanaan (acting), pengamatan (observing), dan refleksi (reflection). Jenis data yang dikumpulkan dan instrumen penelitian yang digunakan ditunjukkan oleh Tabel 2 berikut ini.

Tabel 2. Teknik Pengumpulan Data dan Instrumen

\begin{tabular}{clclll}
\hline No. & Jenis Data & Sumber Data & Instrumen & Waktu \\
\hline 1 & Kemampuan & Siswa & Tes & kemampuan & Setiap akhir siklus \\
& berpikir kritis & & berpikir kritis & \\
2 & Sikap ilmiah & Siswa & Angket sikap & Setiap akhir siklus \\
3 & Tanggapan siswa & Siswa & Angket tanggapan & Akhir siklus II \\
\hline
\end{tabular}


Data dianalisis deskriptif kuantitatif. Kriteria keberhasilan kemampuan berpikir kritis apabila nilai rata-rata kemampuan berpikir kritis siswa berada pada kategori baik. Kriteria Ketuntasan Minimal (KKM) mata pelajaran fisika pada kelas X IPA SMA Negeri 1 Kuta adalah 70 dan memenuhi Ketuntasan Klasikal $(\mathrm{KK}) \geq 75 \%$. Kriteria keberhasilan untuk sikap ilmiah dan tanggapan siswa adalah jika memperoleh hasil minimal masing-masing berada pada ketegori tinggi dan positif.

\section{HASIL DAN PEMBAHASAN}

Hasil analisis data kemampuan berpikir kritis siswa pada siklus I disajikan pada Tabel 3 berikut ini.

Tabel 3. Sebaran Nilai Kemampuan Berpikir Krisis Siswa Siklus I

\begin{tabular}{|c|c|c|c|c|}
\hline No. & Kriteria & Kategori & Frekuensi & Persentase \\
\hline 1 & $85-100$ & Sangat baik & 6 & $17,14 \%$ \\
\hline 2 & $70-84$ & Baik & 26 & $74,29 \%$ \\
\hline 3 & $55-69$ & Cukup & 3 & $8,57 \%$ \\
\hline 4 & $40-54$ & Kurang & 0 & $0 \%$ \\
\hline 5 & $0-39$ & Sangat Kurang & 0 & $0 \%$ \\
\hline \multicolumn{3}{|c|}{ Jumlah } & 35 & $100 \%$ \\
\hline
\end{tabular}

Pada Tabel 3 menunjukkan nilai kemampuan berpikir kritis dalam kategori baik dengan nilai rata-rata 76,37 dan siswa yang belum mencapai syarat KKM sebanyak 3 orang siswa sehingga ketuntasan klasikal mencapai $91,43 \%$. Hasil nilai rata-rata kemampuan berpikir kritis siswa per dimensi pada siklus I disajikan pada Tabel 4.

Tabel 4. Data Hasil Kemampuan Berpikir Kritis Siswa Per Dimensi Siklus I

\begin{tabular}{clcc}
\hline No. & \multicolumn{1}{c}{ Dimensi KBK } & Nilai Rata-Rata & Kategori \\
\hline 1 & Merumuskan masalah & 88,57 & Sangat Baik \\
2 & Memberikan argumen & 76,07 & Baik \\
3 & Melakukan deduksi & 78,93 & Baik \\
4 & Melakukan induksi & 66,43 & Cukup \\
5 & Melakukan evaluasi & 85,36 & Sangat Baik \\
6 & Memutuskan dan melaksanakan & 62,86 & Cukup \\
\hline
\end{tabular}

Pada Tabel 4 menunjukkan terdapat dua dimensi kemampuan berpikir kritis siswa yang berada pada kategori cukup, yaitu pada dimensi melakukan induksi dan memutuskan dan melaksanakan. Hasil kemampuan berpikir kritis siswa pada siklus II disajikan pada Tabel 5 berikut ini.

Tabel 5. Sebaran Nilai Kemampuan Berpikir Kritis Siswa Siklus II

\begin{tabular}{|c|c|c|c|c|}
\hline No. & Kriteria & Kategori & Frekuensi & Persentase \\
\hline 1 & $85-100$ & Sangat baik & 27 & $77,14 \%$ \\
\hline 2 & $70-84$ & Baik & 8 & $22,86 \%$ \\
\hline 3 & $55-69$ & Cukup & 0 & $0 \%$ \\
\hline 4 & $40-54$ & Kurang & 0 & $0 \%$ \\
\hline 5 & $0-39$ & Sangat Kurang & 0 & $0 \%$ \\
\hline \multicolumn{3}{|c|}{ Jumlah } & 35 & $100 \%$ \\
\hline
\end{tabular}

Pada Tabel 5 menunjukkan siswa lebih banyak berada pada kategori sangat baik dan sudah tidak ada siswa yang berada pada kategori cukup seperti pada siklus I. Skor rata-rata kemampuan berpikir kritis siswa pada siklus II adalah 89,58 yang tergolong kategori sangat baik dengan ketuntasan klasikal sebesar $100 \%$. Hasil nilai rata-rata kemampuan berpikir kritis siswa per dimensi pada siklus I disajikan pada Tabel 6.

Tabel 6. Data Hasil Kemampuan Berpikir Kritis Siswa Per Dimensi Siklus II 


\begin{tabular}{clcc}
\hline No. & \multicolumn{1}{c}{ Dimensi KBK } & Nilai Rata-Rata & Kategori \\
\hline 1 & Merumuskan masalah & 98,57 & Sangat Baik \\
2 & Memberikan argumen & 87,50 & Sangat Baik \\
3 & Melakukan deduksi & 91,43 & Sangat Baik \\
4 & Melakukan induksi & 88,93 & Sangat Baik \\
5 & Melakukan evaluasi & 92,50 & Sangat Baik \\
6 & Memutuskan dan melaksanakan & 78,57 & Baik \\
\hline
\end{tabular}

Berdasarkan Tabel 6 dapat dilihat bahwa dimensi kemampuan berpikir kritis sudah berada pada kategori baik dan sangat baik. Perbandingan skor kemampuan berpikir kritis siswa pada siklus I dan II ditunjukkan pada Gambar 1.

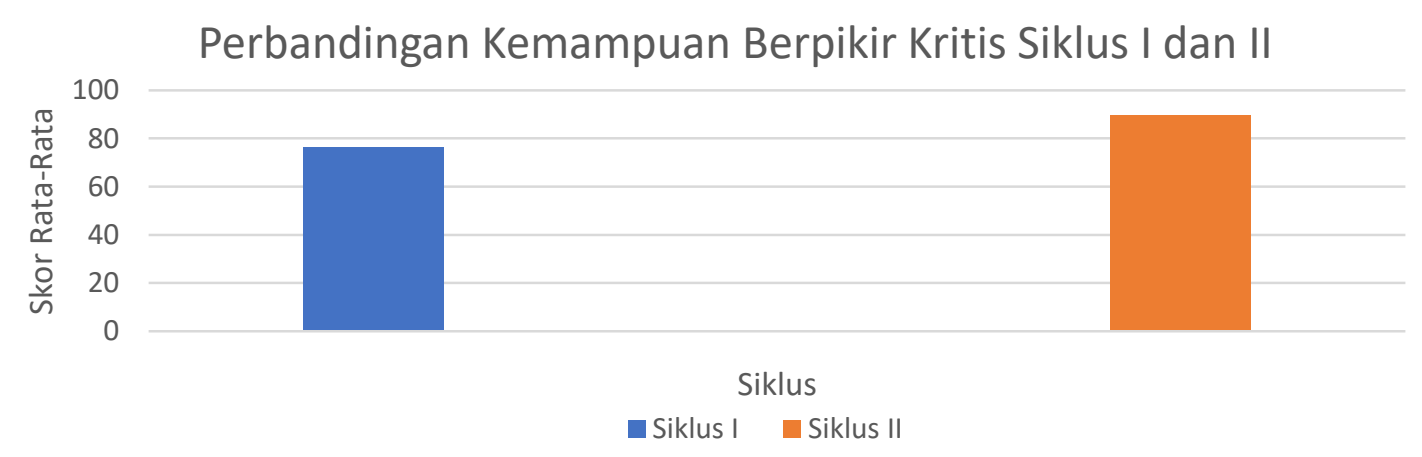

Gambar 1. Diagram Batang Perbandingan Kemampuan Berpikir Kritis Siswa Siklus I dan II

Gambar 1 menunjukkan bahwa nilai rata-rata kemampuan berpikir kritis siswa mengalami peningkatan pada siklus II. Perbandingan nilai rata-rata kemampuan berpikir kritis siswa per dimensi pada siklus I dan II ditunjukkan oleh Gambar 2.

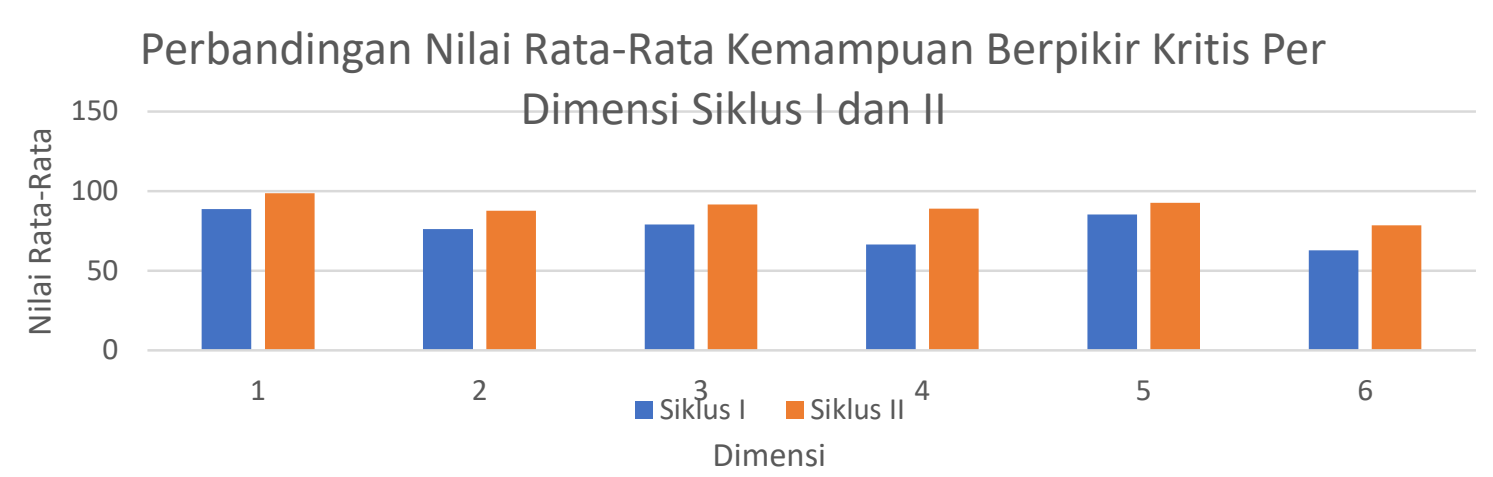

Gambar 2. Diagram Batang Perbandingan Nilai Rata-Rata Kemampuan Berpikir Kritis Siswa Per Dimensi Siklus I dan II

Gambar 2 menunjukkan bahwa nilai rata-rata kemampuan berpikir kritis per dimensi mengalami peningkatan secara kuantitatif dan kategori pada siklus II. Data sikap ilmiah siswa diperoleh dari penyebaran angket sikap ilmiah siswa siklus I. Hasil analisis data sikap ilmiah siswa pada siklus I disajikan pada Tabel 7.

Tabel 7. Deskripsi Sikap IImiah Siswa Siklus I

\begin{tabular}{ccccc}
\hline No. & Kriteria & Kategori & Frekuensi & Persentase \\
\hline 1 & $\bar{X} \geq 120$ & Sangat Tinggi & 6 & $17,14 \%$ \\
2 & $100 \leq \bar{X}<120$ & Tinggi & 26 & $74,29 \%$
\end{tabular}




\begin{tabular}{ccccc}
\hline No. & Kriteria & Kategori & Frekuensi & Persentase \\
\hline 3 & $80 \leq \bar{X}<100$ & Cukup & 3 & $8,57 \%$ \\
4 & $60 \leq \bar{X}<80$ & Rendah & 0 & $0 \%$ \\
5 & $\bar{X}<60$ & Sangat Kurang & 0 & $0 \%$ \\
\hline & Jumlah & & $\mathbf{3 5}$ & $\mathbf{1 0 0 \%}$ \\
\hline
\end{tabular}

Pada Tabel 7 menunjukkan bahwa skor rata-rata sikap ilmiah siswa adalah 110,60 yang berada pada kategori tinggi. Hasil analisis data skor sikap ilmiah siswa per dimensi pada siklus I disajikan pada Tabel 8.

Tabel 8. Data Hasil Skor Rata-Rata Sikap IImiah Per Dimensi Siklus I

\begin{tabular}{clcccc}
\hline No. & \multicolumn{1}{c}{ Dimensi } & $\begin{array}{c}\text { Skor } \\
\text { Maksimum }\end{array}$ & $\begin{array}{c}\text { Skor } \\
\text { Rata-Rata }\end{array}$ & $\begin{array}{c}\text { Nilai } \\
\text { Konversi }\end{array}$ & Kategori \\
\hline 1 & Sikap rasa ingin tahu & 30 & 21,40 & 107,00 & Tinggi \\
2 & $\begin{array}{l}\text { Sikap respek terhadap data atau } \\
\text { fakta }\end{array}$ & 30 & 22,00 & 110,00 & Tinggi \\
3 & $\begin{array}{l}\text { Sikap Fleksibbelitas dalam cara } \\
\text { berpikir }\end{array}$ & 35 & & & Tinggi \\
4 & Sikap Berpikir Kritis & 30 & 25,91 & 111,06 & \\
5 & Sikap Peka Terhadap Lingkungan & 25 & 19,20 & 110,42 & Tinggi \\
\hline
\end{tabular}

Tabel 8 menunjukkan bahwa skor rata-rata sikap ilmiah siswa per dimensi pada siklus I berada pada kategori tinggi. Hasil analisis data sikap ilmiah siswa pada siklus II disajikan pada Tabel 9.

Tabel 9. Deskripsi Sikap IImiah Siswa Siklus II

\begin{tabular}{|c|c|c|c|c|}
\hline No. & Kriteria & Kategori & Frekuensi & Persentase \\
\hline 1 & $\bar{X} \geq 120$ & Sangat Tinggi & 13 & $37,14 \%$ \\
\hline 2 & $100 \leq \bar{X}<120$ & Tinggi & 22 & $62,86 \%$ \\
\hline 3 & $80 \leq \bar{X}<100$ & Cukup & 0 & $0 \%$ \\
\hline 4 & $60 \leq \bar{X}<80$ & Rendah & 0 & $0 \%$ \\
\hline 5 & $\bar{X}<60$ & Sangat Kurang & 0 & $0 \%$ \\
\hline \multicolumn{3}{|c|}{ Jumlah } & 35 & $100 \%$ \\
\hline
\end{tabular}

Pada Tabel 9 menunjukkan bahwa skor rata-rata sikap ilmiah siswa adalah 118,83 yang berada pada kategori tinggi. Skor rata-rata sikap ilmiah siswa pada siklus II sudah menunjukkan peningkatan dibandingkan dengan skor rata-rata sikap ilmiah pada siklus I, yaitu 110,60. Penelitian ini dikatakan berhasil jika mencapai kategori minimal pada kategori tinggi. Hasil data skor sikap ilmiah siswa per dimensi pada siklus II disajikan pada Tabel 10.

Tabel 10. Data Hasil Skor Rata-Rata Sikap IImiah Siswa Per Dimensi Siklus II

\begin{tabular}{clcccc}
\hline No & \multicolumn{1}{c}{ Dimensi } & $\begin{array}{c}\text { Skor } \\
\text { Maksimum }\end{array}$ & $\begin{array}{c}\text { Skor Rata- } \\
\text { Rata }\end{array}$ & $\begin{array}{c}\text { Nilai } \\
\text { Konversi }\end{array}$ & Kategori \\
\hline 1 & $\begin{array}{l}\text { Sikap rasa ingin tahu } \\
2\end{array}$ & 30 & 23,94 & 119,71 & Tinggi \\
& $\begin{array}{l}\text { Sikap respek terhadap } \\
\text { data atau fakta }\end{array}$ & 30 & 23,86 & 119,29 & Tinggi \\
3 & $\begin{array}{l}\text { Sikap Fleksibilitas dalam } \\
\text { cara berpikir }\end{array}$ & 35 & 28,11 & 120,49 & Sangat Tinggi \\
4 & Sikap Berpikir Kritis & 30 & 22,82 & 114,14 & Tinggi \\
5 & $\begin{array}{l}\text { Sikap Peka Terhadap } \\
\text { Lingkungan }\end{array}$ & 25 & 20,08 & 120,51 & Sangat Tinggi \\
\hline
\end{tabular}


Tabel 10 menunjukkan skor rata-rata sikap ilmiah siswa per dimensi menunjukkan kategori tinggi dan sangat tinggi pada dua dimensi, yaitu sikap fleksibilitas dalam cara berpikir dan sikap peka terhadap lingkungan. Perbandingan skor rata-rata sikap ilmiah siswa siklus I dan II ditunjukkan oleh Gambar 3.

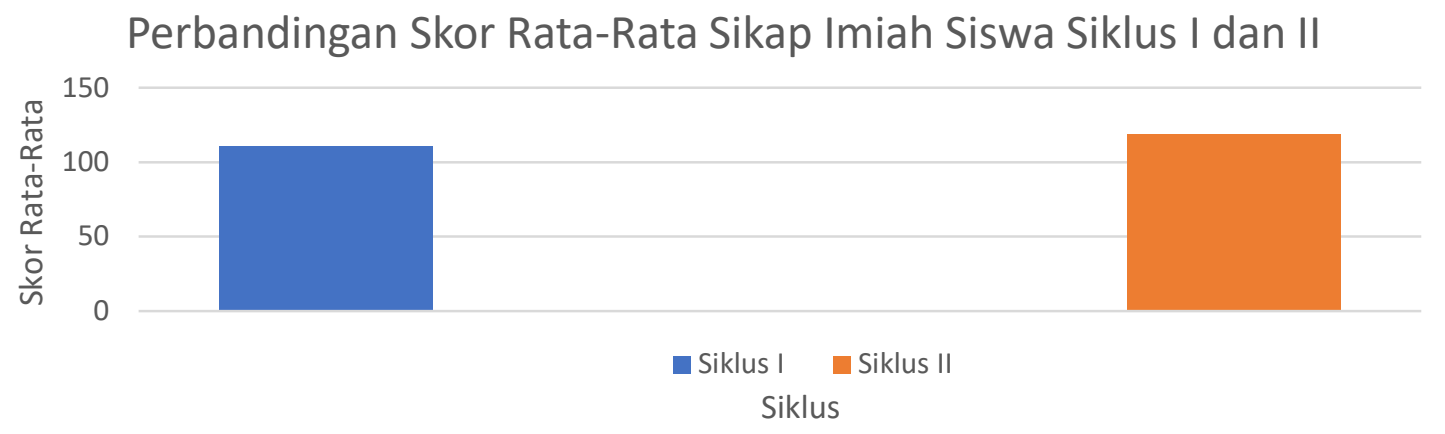

Gambar 3. Diagram Batang Perbandingan Skor Rata-Rata Sikap IImiah Siswa Siklus I dan II

Gambar 3 menunjukkan peningkatan skor rata-rata sikap ilmiah siswa. Peningkatan skor rata-rata sikap ilmiah siswa per dimensi pada siklus I dan II ditunjukkan oleh Gambar 4.

\section{Perbandingan Skor Rata-Rata Sikap Imiah Siswa Siklus I dan II}

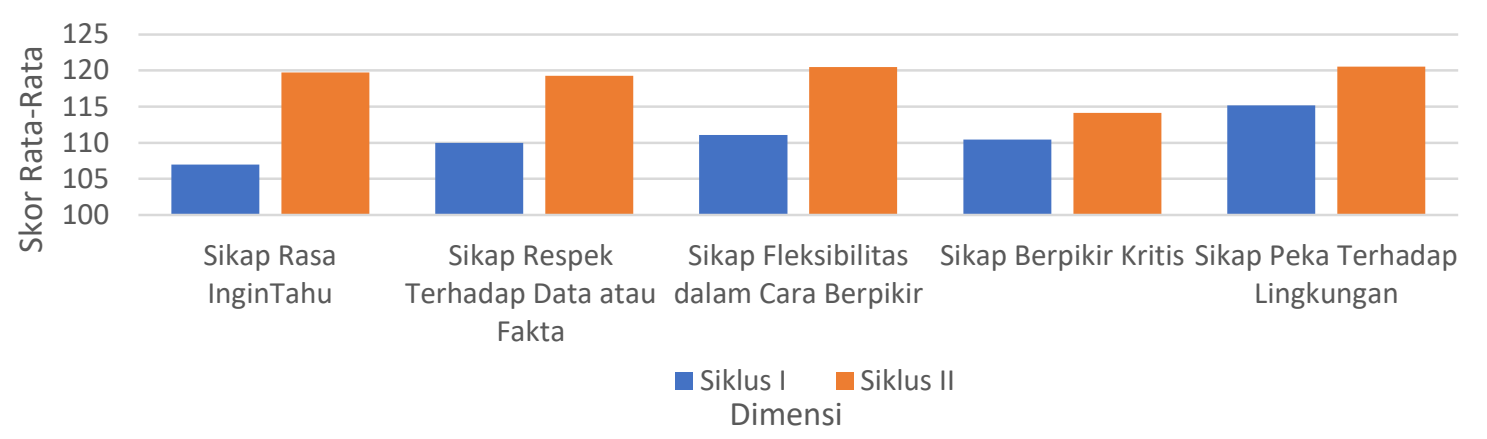

Gambar 4. Diagram Batang Skor Rata-Rata Sikap IImiah Siswa Siklus I dan II

Gambar 4 menunjukkan bahwa skor rata-rata sikap ilmiah per dimensi mengalami peningkatan pada siklus II. Hasil analisis data tanggapan siswa terhadap penerapan model pembelajaran inkuiri terbimbing ditunjukkan pada Tabel 11.

Tabel 9. Profil Tanggapan Siswa Terhadap Penerapan Model Inkuiri Terbimbing

\begin{tabular}{ccccc}
\hline No. & Kriteria & Kategori & Frekuensi & Persentase \\
\hline 1 & $\bar{X} \geq 120$ & Sangat Positif & 6 & $17,14 \%$ \\
2 & $100 \leq \bar{X}<120$ & Positif & 28 & $80 \%$ \\
3 & $80 \leq \bar{X}<100$ & Cukup & 1 & $2,86 \%$ \\
4 & $60 \leq \bar{X}<80$ & Kurang & 0 & $0 \%$ \\
5 & $\bar{X}<60$ & Sangat Kurang & 0 & $0 \%$ \\
\hline \multicolumn{7}{r}{ Jumlah } & & $\mathbf{3 5}$ & $\mathbf{1 0 0 \%}$ \\
\hline
\end{tabular}

Berdasarkan Tabel 11 skor rata-rata tanggapan siswa sebesar 114,11 yang berada pada kategori positif. Sehingga, dapat diindikasikan bahwa siswa dapat menerima penerapan model inkuiri terbimbing yang telah dilakukan.

Berdasarkan analisis terungkap bahwa penelitian yang dilaksanakan di kelas X IPA 2 SMA Negeri 1 Kuta Tahun Pelajaran 2019/2020 selama dua siklus dengan materi 
momentum, impuls dan tumbukan serta getaran harmonis menunjukkan adanya peningkatan kemampuan berpikir kritis siswa dari kategori baik pada siklus I menjadi kategori sangat baik pada siklus II dan peningkatan sikap ilmiah siswa yang berada pada kategori positif.

Hasil analisis data menunjukkan bahwa rata-rata kemampuan berpikir kritis siswa kelas X IPA 2 berada pada kategori baik dengan nilai rata-rata 76,37 dengan ketuntasan klasikal $91,43 \%$. Secara umum, meskipun kemampuan berpikir kritis siswa pada kategori baik, namun masih ditemukan kelemahan, yaitu belum maksimalnya kemampuan berpikir kritis siswa pada dimensi melakukan induksi dan memutuskan dan melaksanakan yang berada pada kategori cukup.

Hasil analisis nilai rata-rata kemampuan berpikir kritis mengalami peningkatan pada siklus II, yaitu 89,58 berada pada kategori sangat baik dengan ketuntasan klasikal $100 \%$. Kelemahan pada siklus I, yaitu belum maksimalnya kemampuan berpikir kritis siswa pada dimensi melakukan induksi dan memutuskan dan melaksanakan yang berada pada kategori cukup pada siklus II ini sudah mengalami peningkatan mencapai kategori baik

Meningkatnya kemampuan berpikir kritis siswa dengan model pembelajaran inkuiri terbimbing dapat dilihat dari langkah-langkah model pembelajarannya. Pada langkah pertama, yakni merumuskan masalah. Langkah ini sesuai dengan dimensi pertama berpikir kritis. Saat merumuskan masalah siswa diberikan sebuah permasalahan dalam bentuk fenomena fisika, kemudian siswa melakukan diskusi dengan anggota kelompoknya dan merumuskan masalah sesuai narasi serta merumuskannya dalam bentuk pertanyaan. Selain merumuskan masalah, saat melakukan diskusi juga terjadi saling memberikan argumen. Pada langkah kedua, yakni merumuskan hipotesis, siswa memberikan jawaban sementara atas permasalahan yang sudah dikaji sebelumnya. Pada langkah ini siswa memberikan argumen mereka berdasarkan sumber-sumber belajar seperti buku dan internet. Pada langkah ketiga, yakni merancang dan melakukan percobaan, siswa merancang percobaan berdasarkan petunjuk-petunjuk yang terdapat pada LKS dan melakukan percobaan dengan saling bekerja sama dengan teman kelompoknya. Dalam tahap ini siswa menekankan pada dimensi memutuskan dan melaksanakan, yaitu siswa memilih alternatif yang ada dan menentukan kemungkinan solusi dalam kendala melakukan percobaan. Tahap keempat, yakni mengumpulkan dan mengolah data, siswa melakukan induksi, yaitu melakukan investigasi atau pengumpulan data secara lengkap. Tahap kelima, yakni interpretasi hasil analisis data dan pembahasan, siswa melakukan deduksi dan evaluasi terhadap hasil data yang diperoleh. Tahap keenam, yakni menarik kesimpulan. Pada tahap ini siswa membuat kesimpulan dan setelah kesimpulan selesai salah satu kelompok akan mempresentasikan hasil diskusinya. Aspek kemampuan berpikir kritis yang terukur adalah memberikan argumen, melakukan evaluasi, dan memutuskan dan melaksanakan.

Berdasarkan langkah-langkah dalam model pembelajaran inkuiri terbimbing, tampak bahwa model pembelajaran inkuiri terbimbing dapat menuntun siswa untuk mengembangkan kemampuan berpikir kritis dalam proses pembelajaran. Proses pembelajaran menjadi berpusat pada siswa dan guru dapat mengoptimalkan perannya sebagai fasilitator dan mediator.

Hasil penelitian ini secara empiris sejalan dengan hasil penelitian Seranica et al. (2018) dan Cahyani dan Azizah (2019) yang mengungkapkan bahwa penerapan model pembelajaran inkuiri terbimbing dapat meningkatkan keterampilan berpikir kritis peserta didik. Penelitian Amijaya et al. (2018) juga mengemukakan penelitian serupa bahwa penerapan model pembelajaran inkuiri berpengaruh positif terhadap hasil belajar dan kemampuan berpikir kritis peserta didik. Penelitian ini juga menunjukkan bahwa hasil belajar peserta didik dan kemampuan berpikir kritis kelas yang menerapkan model pembelajaran inkuiri terbimbing lebih baik daripada kelas yang menerapkan pembelajaran konvensional.

Hasil analisis data menunjukkan bahwa skor rata-rata sikap ilmiah siswa kelas X IPA 2 pada siklus I sebesar 110,60 dan berada pada kategori tinggi. Semua dimensi sikap ilmiah pada siklus satu, yaitu sikap rasa ingin tahu, sikap respek terhadap data atau fakta, sikap fleksibilitas dalam cara berpikir, sikap berpikir kritis, dan sikap peka terhadap lingkungan berada pada kategori tinggi. Di antara kelima dimensi tersebut, dimensi sikap rasa ingin tahu menunjukkan skor paling kecil, yaitu 107. 
Pada siklus II, skor rata-rata sikap ilmiah siswa meningkat jika dibandingkan dengan siklus I mencapai 118,83 dengan kategori tinggi. Semua dimensi pada siklus II sudah meningkat dan mencapai kategori tinggi dan sangat tinggi pada dimensi sikap fleksibilitas dalam cara berpikir dan sikap peka terhadap lingkungan. Pada siklus II terjadi peningkatan kuantitas dan kategori sikap ilmiah siswa. Penelitian ini dikatakan berhasil apabila sikap ilmiah siswa berada pada kategori tinggi.

Langkah-langkah model pembelajaran inkuiri terbimbing menuntun siswa dalam meningkatkan sikap ilmiah. Langkah pertama dan kedua, siswa akan memunculkan sikap rasa ingin tahu dengan berbagai pertanyaan-pertanyaan dan mencari serta menggunakan sumber-sumber informasi mengenai hal-hal yang baru. Langkah ketiga, siswa bersikap berpikir kritis dengan mengulangi kegiatan percobaan yang dilakukan untuk memperoleh hasil percobaan yang sesuai. Setelah melakukan percobaan siswa akan dilatih untuk bersikap peka terhadap lingkungan, seperti mengamati kejadian sekitar dan menjaga kebersihan laboratorium yang digunakan. Langkah keempat, siswa mengumpulkan dan mengolah data. Siswa dapat meningkatkan sikap respek terhadap fakta atau data yang diperoleh pada saat melakukan percobaan, seperti tidak memanipulasi data atau mengambil keputusan sesuai fakta Langkah kelima, dalam interpretasi hasil analisis data dan pembahasan menuntun siswa untuk memiliki sikap fleksibilitas dalam cara berpikir dan berpikir kritis. Siswa mampu mengubah pandangan awal ketika terdapat fakta baru yang tidak sesuai dengan pandangan awal mereka. Langkah keenam, yakni menarik kesimpulan. Siswa akan memiliki sikap respek terhadap data atau fakta, yaitu dengan meragukan kesimpulan dengan bukti-bukti yang belum cukup.

Hasil penelitian ini secara empiris sejalan dengan hasil penelitian Fadilah et al. (2018) yang mengungkapkan bahwa penerapan model pembelajaran inkuiri terbimbing dapat meningkatkan sikap ilmiah dan hasil belajar siswa. Penelitian Sa'adah dan Kusasi (2017) mengemukakan bahwa penerapan model pembelajaran inkuiri terbimbing dapat meningkatkan sikap ilmiah dan pemahaman konsep siswa. Penelitian Sitorus et al. (2017) mengungkapkan bahwa model pembelajaran inkuiri terbimbing berpengaruh terhadap sikap ilmiah siswa jika dibandingkan dengan model inkuiri bebas dan model pembelajaran konvensional.

Berdasarkan hasil analisis angket tanggapan siswa terhadap penerapan model pembelajaran inkuiri terbimbing yang disebar pada akhir siklus II mencapai skor rata-rata sebesar 114, 11 yang berada pada kategori positif. Fakta ini menunjukkan bahwa siswa dapat menerima penerapan model pembelajaran inkuiri terbimbing yang telah dilakukan. Tanggapan positif ini menandakan bahwa model pembelajaran inkuiri terbimbing tergolong efektif diterapkan untuk menyelesaikan masalah yang teridentifikasi di kelas X IPA 2 SMA Negeri 1 Kuta. Penelitian ini dapat dikatakan berhasil apabila tanggapan siswa minimal berada pada kategori positif. Selain itu, wawancara dengan beberapa siswa menyatakan bahwa pembelajaran yang diterapkan pada momentum, impuls, dan tumbukan serta getaran harmonis memberikan pengalaman yang lebih bagi siswa dan siswa menjadi memahami konsep yang diberikan.

\section{SIMPULAN DAN SARAN}

Berdasarkan hasil penelitian dan pembahasan yang telah diuraikan pada bab sebelumnya, maka dapat disimpulkan beberapa hal sebagai berikut.

1. Penerapan model pembelajaran inkuiri terbimbing dapat meningkatkan kemampuan berpikir kritis siswa dalam pelajaran fisika kelas X IPA 2 SMA Negeri 1 Kuta Tahun Pelajaran 2019/2020. Nilai rata-rata kemampuan berpikir kritis siswa pada siklus I sebesar 76,37 berada pada kategori baik dengan standar deviasi 7,76 dan nilai ratarata pada siklus II sebesar 89,58 berada pada kategori sangat baik dengan standar deviasi 6,60.

2. Penerapan model pembelajaran inkuiri terbimbing dapat meningkatkan sikap ilmiah siswa dalam pelajaran fisika kelas X IPA 2 SMA Negeri 1 Kuta Tahun Pelajaran 2019/2020. Skor rata-rata sikap ilmiah siswa pada siklus I adalah 110,60 yang berada 
pada kategori tinggi dengan standar deviasi 7,39 dan skor rata-rata pada siklus II sebesar 118,83 yang berada pada kategori tinggi dengan tandar deviasi 7,35.

3. Tanggapan siswa kelas X IPA 2 SMA Negeri 1 Kuta Tahun Pelajaran 2019/2020 terhadap model pembelajaran inkuiri terbimbing memberikan tanggapan positif dengan skor rata-rata sebesar 114,11.

Berdasarkan hasil penelitian, pembahasan, dan kesimpulan yang telah dilakukan, maka dapat diajukan beberapa saran sebagai berikut.

1. Bagi guru, sebaiknya guru memperhatikan alokasi waktu untuk setiap langkah model pembelajaran inkuiri terbimbing dan mempersiapkan alat dan bahan yang digunakan. Hal ini agar proses pembelajaran berjalan lancar sesuai dengan yang direncanakan.

2. Bagi siswa, sebaiknya belajar sebelum proses pembelajaran dimulai. Siswa dapat membaca dan memahami petunjuk yang diberikan agar terbiasa mencari informasso sendiri tanpa menerima pengetahuan yang diberikan oleh guru.

3. Bagi sekolah, hendaknya untuk mempertimbangkan jumlah siswa yang terdapat dalam satu kelas. Jumlah 35 orang siswa dengan kelompok belajar yang terbagi menjadi 6 kelompok menyebabkan guru kurang optimal dalam memfasilitasi siswa. Sehingga menghambat proses pembelajaran.

\section{DAFTAR PUSTAKA}

Amijaya, L. S., Ramdani, A., \& Merta, W. (2018). Pengaruh model pembelajaran inkuiri terbimbing terhadap hasil belajar dan kemampuan berpikir kritis peserta didik. Jurnal Pijar MIPA, 14(1), 94-99. Tersedia pada https://jurnalfkip.unram.ac.id/index.php/JPM/article/view/468. Diakses 7 Oktober 2019.

Cahyani, N. I., \& Azizah, U. (2019). Penerapan model pembelajaran inkuiri terbimbing untuk melatihkan keterampilan berpikir kritis pada materi laju reaksi kelas XI SMA. UNESA Journal of Chemistry Education, 8(3), 320-326. Tersedia pada http://jurnalmahasiswa. unesa.ac.id/index.php/journal-of-chemical-education/article/view/30546. Diakses 7 Oktober 2019.

Costa, A. L. (1991). Developing mind: a resource book for teaching thinking. Terdapat pada http://files.eric.ed.gov/fulltext/ED332166.pdf. Diakses 9 Oktober 2019.

Fadilah, S., Purwanto, A., \& Risdianto, E. (2018). Penerapan model inkuiri terbimbing untuk meningkatkan sikap ilmiah dan hasil belajar siswa pada konsep alat-alat optik kelas XI SMAN 1 Mukomuko. Jurnal Kumparan Fisika, 1(2), 8-14. Tersedia pada https://ejournal.unib.ac.id/index.php/ kumparan_fisika/article/view/6223. Diakses 6 Oktober 2019.

Fauzia, D. P., Badarudin, \& Supriatna (2019). Peningkatkan keterampilan berpikir kritis dan sikap ilmiah peserta didik melalui model inkuiri terbimbing. Muallimuna : Jurnal Madrasah Ibtidaiyah, 4(2), 57-66. Tersedia pada https://ojs.uniskabjm.ac.id/index.php/jurnal-muallimuna/article/view/1860. Diakses 6 Oktober 2019.

Fisher, A. (2007). Berpikir kritis: sebuah pengantar. Surabaya: Erlangga.

Hajrin, M., Sadia, I. W., \& Gunadi, I. G. A. (2019). Pengaruh model pembelajaran inkuiri terbimbing terhadap berpikir kritis siswa pada pembelajaran fisika kelas X IPA SMA Negeri. Jurnal Pendidikan Fisika Undiksha, 9(1), 63-74. Tersedia pada https://ejournal.undiksha.ac.id/index.php/JJPF/issue/view/ 1179. Diakses 6 Oktober 2019.

Harlen, W. (2000). Teaching, learning and assessing science 5-12. London: Paul Chapman Publishing. 
Harlen, W., \& Qualter, A. (2004). The teaching of science in primary school (fourth edition). London: David Fulton Publiser.

Laila, N., \& Lufri. (2019). The influence of guided inquiry learning model with LKPD assistance on attitude competencies of class XI students of SMAN 1 Sungayang. International Journal of Progressive Science and Thechnologies, 15(2), 171-175. Tersedia pada http://ijpsat.ijsht-journals.org. Diakses 6 Oktober 2019.

Nisa, E. K., Koestiari, T., Habibbulloh, M., \& Jatmiko, B. (2018). Effectiveness of guided inquiry learning model to improve students' critical thinking skills at senior high school. Journal of Physics: Conference Series, 4, 012049. Tersedia pada https://iopscience.iop.org. Diakses 15 Desember 2019.

Nurdin, H., Jalmo, T., \& Ertikanto, C. (2018). Effectiveness of guided inquiry model student worksheet to improve critical thinking skill on heat material. International Journal of Advanced Engineering, Management and Science, 4(7), 564-573. Tersedia pada https://ijaems.com. Diakses 15 Desember 2019.

Permendikbud No. 59. (2014). Kurikulum 2013 sekolah menengah atas/madrasah aliyah. Tersedia pada https://jdih.kemdikbud.go.id/. Diakses 15 Desember 2019.

Sa'adah \& Kusasi, M. (2017). Meningkatkan sikap ilmiah dan pemahaman konsep menggunakan model pembelajaran inkuiri terbimbing (guided inquiry) pada materi kesetimbangan kimia. QUANTUM, Jurnal Inovasi Pendidikan Sains, 8(1), 78-88. Tersedia pada https://ppjp.ulm.ac.id/journal/index.php/quantum/ article/view/3861. Diakses 6 Oktober 2019.

Sadia, I. W. (2014). Model-model pembelajaran sains kontruktivistik. Yogyakarta: Graha IImu.

Seranica, C., Purwoko, A. A., \& Hakim, A. (2018). Influence of guided inquiry learning model to critical thinking skill. IOSR Journal of Research \& Method in Education, 12(4), 407422. Tersedia pada www.iosrjounals.org. Diakses 6 Oktober 2019.

Siburian, J., Corebima, A. D., Ibrohim, \& Saptasari, M. (2019). The correlation between critical and creative thinking skill on cognitive learning result. Eurasian Journal of Educational Research, 19(81), 99-114. Tersedia pada http://ejer.com.tr. Diakses 6 Oktober 2019.

Sitorus, H. H., Hasruddin, \& Edi, S. (2017). The influence of inquiry learning model on student's scientific attitudes in ecosystem topic at MTs. Daarul Hikmah Sei Alim (islamic junior high school) Asahan. International Journal of Humanities, Social Science and Education, 4(11), 170-175. Tersedia pada https://www.arcjournals.org/. Diakses 15 Desember 2019.

Wildan,W., Hakim A., Siahaan, J., \& Anwar, Y. A. S. (2019). A stepwise inquiry approach to improving communication skill and scientific attitude on biochemistry course. International Journal of Instruction, 12(4), 407-422. Tersedia pada www.e-iji.net. Diakses 6 Oktober 2019. 